\title{
Psychopharmacology at the era of EMEA (European Medicines Agency)
}

\author{
Luis Camara Pestana', Licinia Gananca ${ }^{2 *}$ \\ From $1^{\text {st }}$ International Congress on Neurobiology and Clinical Psychopharmacology and European \\ Psychiatric Association Conference on Treatment Guidance \\ Thessaloniki, Greece. 19-22 November 2009
}

In the last decade the European Medicines Agency has been attempting to harmonize the work of the existing national medicines regulatory authorities and the data regarding efficacy criteria and safety for the use of human medicines in specific pathologies (eg. Schizophrenia, Bipolar Disorder, Depression), thus creating guidance notes for clinical investigation. Medical prescription decisions are generally made upon data acquired through scientific information (treatise, studies, consensus, meetings, congresses), specialists experience and pharmaceutical industry information. While prescription rules are established for approved indications by large scale studies, off-label prescribing lacks the support of robust clinical trials and is at its best based on expert consensus. It brings with it increased responsibility for the prescriber if the patient suffered an adverse reaction, as liability would rest with the prescriber and/ or their employers. Nuclear information for a rational plan, risk assessment, scientific evidence for add-on therapy and off-label prescription, will be discussed in this presentation.

\section{Author details}

${ }^{1}$ Portuguese Association of Biological Psychiatry and Portuguese Authority of Drugs and Pharmacy, Portugal. ${ }^{2}$ Psychiatric Department, Hospital Santa Maria, University of Lisbon and consultant of the Portuguese Authority of Drugs and Pharmacy, Portugal.

Published: 22 April 2010

doi:10.1186/1744-859X-9-S1-S73

Cite this article as: Pestana and Gananca: Psychopharmacology at the era of EMEA (European Medicines Agency). Annals of General Psychiatry 2010 9(Suppl 1):S73.

\footnotetext{
${ }^{2}$ Psychiatric Department, Hospital Santa Maria, University of Lisbon and consultant of the Portuguese Authority of Drugs and Pharmacy, Portugal
}

Submit your next manuscript to BioMed Central and take full advantage of:

- Convenient online submission

- Thorough peer review

- No space constraints or color figure charges

- Immediate publication on acceptance

- Inclusion in PubMed, CAS, Scopus and Google Scholar

- Research which is freely available for redistribution

Submit your manuscript at www.biomedcentral.com/submit
C Biomed Central 